\title{
Molecular typing, biofilm production, and detection of carbapenemase genes in multidrug-resistant Acinetobacter baumannii isolated from different infection sites using ERIC-PCR in Hamadan, west of Iran
}

\author{
Maryam Hazhirkamal ${ }^{1}$, Omid Zarei ${ }^{1}$, Mahsa Movahedi ${ }^{1}$, Pezhman Karami², Leili Shokoohizadeh² and
} Mohammad Taheri ${ }^{*}$

\begin{abstract}
Background: Acinetobacter baumannii is an opportunistic pathogen that can cause several kinds of nosocomial infections. Increasing antibiotic resistance as well as identifying genetic diversity and factors associated with pathogenicity and prevalence of this bacterium is important. The aim of this study was the investigation of molecular typing, biofilm production, and detection of carbapenemase genes in multidrug-resistant Acinetobacter baumannii isolated from different infection sites using ERIC-PCR in Iran.

Methods: Forty isolates of $A$. baumannii were obtained from various wards of the central hospital, in the west of Iran. Phenotypic identification and genetic diversity, biofilm production assay, and detection of Carbapenemase genes carried out.

Results: Tracheal samples 26 (61.9\%) are the most frequent isolates, and $95 \%$ of isolates were identified as MDR. $32.5 \%$ of all A. baumannii strains were capable to form a strong biofilm. It was founded that antimicrobial resistance patterns had a significant relationship with strong biofilm formation $(P=0.001)$. Most frequencies of the studied genes were in the order of VIM (81\%), SPM (45.2\%), and IMP (35.7\%) genes. The VIM gene was the most frequent in all isolates which were significant $(P=0.006) .14$ different ERIC-types were observed including 7 common types and 7 unique or single types. $F$ type is the largest common type consisting of nine isolates and $B$, $D$, and $E$ types contain two isolates separately.
\end{abstract}

Conclusions: ERIC-PCR technique was used to genetically classify A. baumannii isolates as one of the most common microorganisms in nosocomial infections.

Keywords: Molecular typing, Biofilm formation, MBL, MDR, Acinetobacter baumannii

\footnotetext{
* Correspondence: motaheri360@gmail.com

${ }^{2}$ Department of Microbiology, Faculty of Medicine, Hamadan University of

Medical Sciences, Hamadan, Iran
}

Full list of author information is available at the end of the article

\section{$\triangle B M C$}

(c) The Author(s). 2021 Open Access This article is licensed under a Creative Commons Attribution 4.0 International License, which permits use, sharing, adaptation, distribution and reproduction in any medium or format, as long as you give appropriate credit to the original author(s) and the source, provide a link to the Creative Commons licence, and indicate if changes were made. The images or other third party material in this article are included in the article's Creative Commons licence, unless indicated otherwise in a credit line to the material. If material is not included in the article's Creative Commons licence and your intended use is not permitted by statutory regulation or exceeds the permitted use, you will need to obtain permission directly from the copyright holder. To view a copy of this licence, visit http://creativecommons.org/licenses/by/4.0/ The Creative Commons Public Domain Dedication waiver (http://creativecommons.org/publicdomain/zero/1.0/) applies to the data made available in this article, unless otherwise stated in a credit line to the data. 


\section{Background}

Acinetobacter baumannii is an opportunistic pathogen that can cause several kinds of nosocomial infections, including surgical site infections, skin and soft tissue infections, urinary tract infections (UTI), ventilator-and nosocomial-associated pneumonia, catheter-related bloodstream infections, and secondary meningitis [1, 2]. This bacterium is unique due to enabling it to survive in a variety of conditions for long periods and to colonize on the surfaces and materials in hospitals, enabling its transfer between patients through human reservoirs or inanimate elements $[3,4]$. Besides, this organism exhibits resistance against several types of antibiotics [4]. In light of recent concerns about multidrug-resistant (MDR) and extensively drug-resistant (XDR) isolates, now infections caused by A. baumannii present a public health issue worldwide [5].

In the last decade, carbapenems have been suggested as a choice drug for treating serious infections related to MDR isolates of Acinetobacter [6]. Metallobetalactamase enzymes, which can hydrolyze almost all beta-lactams except monobactams, are one of the most common carbapenem resistance mechanisms. Moreover, genes encoding Metallo- $\beta$-lactamases that are placed on integrons can be transferred from one bacterium to another one easily via plasmids [7]. The IMP, VIM, and SPM genes are related to Metallo- $\beta$-lactamases producers in Acinetobacter that cause resistance to many antimicrobial drugs [8]. Recently, many studies have been emphasized the biofilm formation in A. baumannii, because microbes that present in the biofilm structure have less sensitivity to antimicrobials and are more resistant to environmental situation surfaces such as catheters, intubation tubes, and cleaning types of equipment, which indicates the critical role of biofilm in the treatment failure and increase hospitalization time $[9,10]$.

The study of molecular epidemiological characteristics could help in the management of bacterial spread in hospitals and $A$. baumannii drug resistance $[2,5,11]$. Several important genotypic methods have been introduced, including pulsed-field gel electrophoresis (PFGE) and multilocus sequence typing (MLST), which are used to detect the genotypic relationship of $A$. baumannii strains in hospital settings. Furthermore, PCR-based methods, including enterobacterial repetitive intergenic consensus (ERIC)-PCR, are valuable typing methods for non-fermentative gram-negative bacilli [12, 13]. Molecular typing has a pivotal role in understanding the essential mechanisms of A. baumannii infections and discovering the relationship between bacterial species. Overall, evidence suggests that molecular typing techniques are now an effective method for assessing and defining the primary cause of infection in hospitals [14]. Genotype techniques such as PFGE, MLST, and ERIC-PCR can be used as typing methods in microorganisms, especially bacteria, due to their availability, cost-effectiveness and ability to be done in less time. The ERIC-PCR is a molecular technique used in epidemiological and genotyping studies of bacteria. This method provides great potential to study bacterial sequences because the sequences are longer and do not base on a specific region of the genome. This approach also provides detailed information for researching and comparing the genomes of a wide variety of bacterial species $[15,16]$. The ERIC PCR method can be used to study human pathogens to determine their genetic diversity [17].

The purpose of this study is to investigate the relationship between molecular typing, biofilm formation, and detection of carbapenemase genes in multidrug-resistant A. baumannii isolated from different infections in Hamadan, Iran.

\section{Materials and methods Sample collection}

To begin, all subjects signed a consent form, and all procedures were carried out in compliance with Hamadan's ethics committee guidelines. Forty, A. baumannii isolates were obtained from hospitalized patients in different wards in Hamadan, Iran, were collected from August 2019 to September 2020. To confirm isolates, morphological and biochemical tests including the API method were performed.

\section{Antimicrobial susceptibility testing}

The antimicrobial susceptibility test was determined on the Mueller-Hinton agar (Merck, Germany) using the Kirby Bauer (disc diffusion) method as CLSI 2018 guidelines [18]. The antibiogram test was performed using the antibiotics including Amikacin (30 $\mu \mathrm{g})$, levofloxacin (5 $\mu \mathrm{g})$, co-trimoxazole $(1.25 / 23.75 \mu \mathrm{g})$, Ceftazidime $(30 \mu \mathrm{g})$, piperacillin-tazobactam $(100 \mu \mathrm{g} / 10 \mu \mathrm{g})$, Imipenem $(10 \mu \mathrm{g})$ ampicillin-sulbactam $(10 \mu \mathrm{g} / 10 \mu \mathrm{g}),(10 \mu \mathrm{g})$, meropenem $(10 \mu \mathrm{g})$,. The standard bacterial strain of E.coli (ATCC 25,922) was used as quality control. (MAST, Group Ltd., Merseyside, UK). A. baumannii isolates when they are non-susceptible to at least one agent in three or more antimicrobial categories were considered as multidrug-resistant (MDR) [19].

\section{Biofilm Assay}

The A. baumannii isolates were evaluated for their ability to biofilm formation using microplate. A 0.5 McFarland standard turbidity of $A$. baumannii suspension was prepared; $200 \mu \mathrm{L}$ of suspension was added to each well and incubated overnight at $35{ }^{\circ} \mathrm{C}$. The wells were washed three times with normal saline, then to fix cells, $200 \mu \mathrm{L}$ ethanol (96\%) was added to wells; the good contents were pulled after $15 \mathrm{~min}$, and let's plate was dried 
at room temperature. The staining step was carried out by adding $200 \mu \mathrm{L}$ of $2 \%$ crystal violet for $5 \mathrm{~min}$. After the color removal, $200 \mu \mathrm{L}$ of $33 \%$ acetic acid was added and incubated at $37{ }^{\circ} \mathrm{C}$ for $15 \mathrm{~min}$. Empty wells containing media were considered as a negative control. The absorbance of each well was recorded at $560 \mathrm{~nm}$ using an ELISA reader. For each sample, the biofilm assay was repeated three times, and data were measured.

\section{DNA Extraction and detection of carbapenemase genes}

The isolates were cultured in Luria Bertani (LB) broth and incubated at $35{ }^{\circ} \mathrm{C}$ overnight. DNA extraction was performed via the boiling method. The DNA concentration was determined using nanodrop. The PCR reactions were prepared in $25 \mu \mathrm{l}$ total volume as follow $10 \mu \mathrm{l}$ of Taq DNA Polymerase, Master Mix (Amplicon, Denmark), with $1 \mu \mathrm{l}$ (50 ng) of extracted DNA, $1 \mu \mathrm{l}$ for forward and reverse primers, and sterile deionized water to get a final volume of $25 \mu \mathrm{l}$. The amplifications were carried out in a thermocycler (Bio-Rad, USA), with the following conditions: initial denaturation at $95{ }^{\circ} \mathrm{C}$ for $1 \mathrm{~min}$, followed by 35 cycles of denaturation at $95{ }^{\circ} \mathrm{C}$, for $30 \mathrm{~s}$, annealing $53{ }^{\circ} \mathrm{C}$ for $40 \mathrm{~s}$, and extension at $72{ }^{\circ} \mathrm{C}$ for $90 \mathrm{~s}$ with a final extension at $72{ }^{\circ} \mathrm{C}$ for $4 \mathrm{~min}$ (Table 1 ).

\section{Molecular typing and ERIC-PCR}

In this method, PCR in a reaction with a volume of $50 \mu \mathrm{l}$ including $5 \mu \mathrm{l}$ of PCR buffer10x, $4 \mu \mathrm{l} \mathrm{Mgcl} 2,75 / 1$ $\mu \mathrm{l}$ dNTP Mix, $6 \mu \mathrm{l}$ of Taq DNA Polymerase enzyme, $3 \mu \mathrm{l}$ of primer pairs ERIC1: ATGTAAGCTCCTGGGG ATTCAC and ERIC2: AAGTAAGTGACTGGGGTG AGCG. ERIC-PCR test was performed on each of the isolates 3 times. NTSYS version 2.02e software was used to draw the phylogenetic tree and analyze the images obtained by electrophoresis of the studied samples (Fig. 1). The bands obtained from the electrophoresis of the marker product were scored as quantitative data of zero and one (presence or absence of band). After scoring the gels, the genetic similarity was calculated based on data zero and one using Jaccard and Dice coefficient and simple matching. To determine the efficiency of the ERIC method of cluster analysis based on similarity coefficients, the coefficient of correlation coefficient was used. Then, to group the strains, cluster analysis by method Unweighted Pair Group Method using arithmetic
Averages (UPGMA) was used based on the similarity coefficient that had the highest coefficient of coronary correlation.

\section{Statistical analysis}

The t-test was used to compare categorical results. All statistical tests were two-tailed, and statistical significance was defined as a P-value of 0.05 . The statistical software package SPSS version 22 (IBM, NY) was used to analyze the data.

\section{Results}

Bacterial isolates and antimicrobial susceptibility test In this study, 40 non-duplicated $A$. baumannii isolates were obtained from the various clinical samples, including wounds 5 (11.9\%), CSF 2 (4.8\%) tracheal samples 26 (61.9\%), blood $3(7.1 \%)$, and urine $4(9.5 \%)$ isolates and the mean age of the patients was $33.5 \pm 22.2$ years.

The frequency samples collected from males and females were $23(57.5 \%)$ and $17(42.5 \%)$, respectively in this study. According to antibiotic susceptibility testing, 38 out of 40 (95\%) A. baumannii isolates were identified as MDR. In our study, among 38 MDR $A$. baumannii isolates, were resistant to Ampicillin/Sulbactam 36 (90\%), Amikacin 38 (95\%), Ceftazidime 38 (95\%), Imipenem 39 (97/5\%), Meropenem 38 (95\%), Levofloxacin 36 (90\%), Piperacillin/Tazobactam 39 (97/5\%), Trimethoprim/Sulfamethoxazole 36 (90\%). In addition, all isolates were susceptible to Colistin.

\section{Biofilm formation}

Out of 40 A. baumannii isolates, 13 (32.5\%) of all $A$. baumannii strains produced a strong biofilm, while $10(25 \%)$ and $17(42.5 \%)$ of these isolates were considered as weak and medium biofilm-producer isolates, respectively. Also, this study showed a significant relation of antimicrobial resistance patterns with strong biofilm production $(P=0.001)$. High strong biofilm formation in different clusters showed in Table 2. No significant relationship was observed between biofilm production and clusters.

\section{Detection of carbapenemase genes}

The frequencies of the studied genes are in order of VIM (81\%), SPM (45.2\%), and IMP (35.7\%) genes. The

Table 1 Primers for identification of carbapenemase-producing bacteria

\begin{tabular}{|c|c|c|c|}
\hline Primer & & Size bp & Reference \\
\hline VIM-Family & $\begin{array}{l}\text { F: GATGGTGTTTGGTCGCATA } \\
\text { R: CGAATGCGCAGCACCAG }\end{array}$ & 390 & (Ellington et al., 2006) \\
\hline IMP-Family & $\begin{array}{l}\text { F: GGAATAGAGTGGCTTAAYTCTC } \\
\text { R: CCAAACYACTASGTTATC }\end{array}$ & 188 & (Ellington et al., 2006) \\
\hline SPM-1 & $\begin{array}{l}\text { F: AAAATCTGGGTACGCAAACG } \\
\text { R: ACATTATCCGCTGGAACAGG }\end{array}$ & 271 & (Ellington et al., 2006) \\
\hline
\end{tabular}




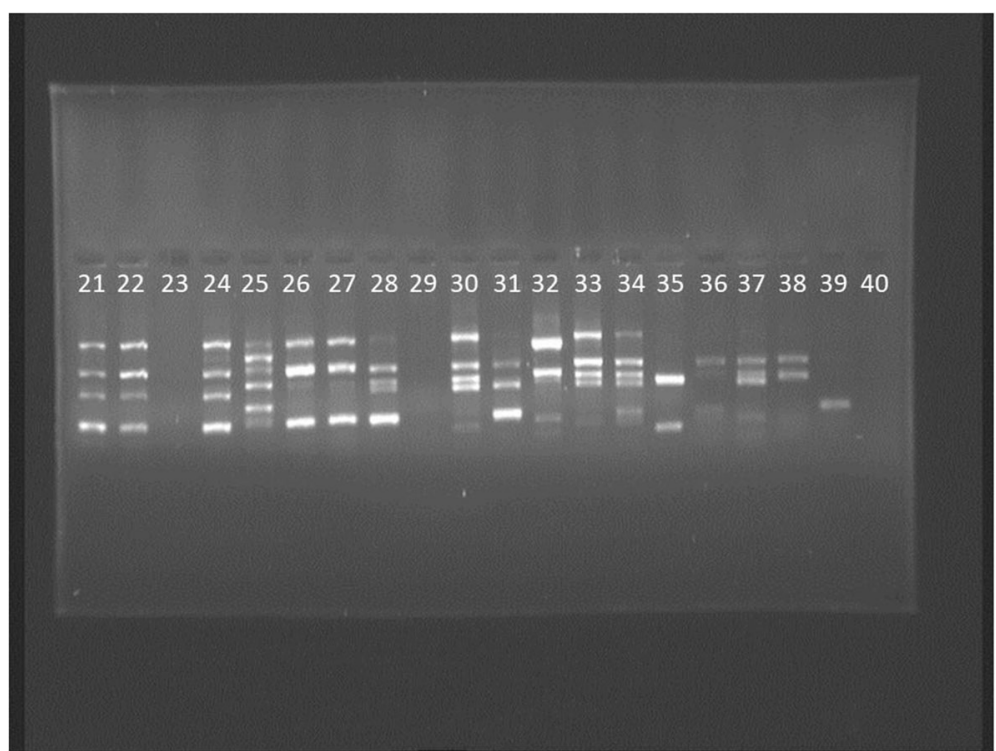

Fig. 1 Agarose gel electrophoresis of ERIC-PCR products of A. baumannii isolates

frequency of carbapenemase encoding genes in different sources is presented in Fig. 2. High-frequency genes in different clusters are presented in Table 2. The VIM gene was the most frequent in all isolates significantly $(P=0.006)$.

\section{ERIC-PCR results}

ERIC-PCR results were analyzed using online software (http://insilico.ehu.es). The one to six ERIC band patterns were observed. A dendrogram was drawn (Fig. 3) and results indicated the existence of genetic diversity in A. baumannii isolates. According to Tables 3 and 14 different ERIC-types were observed including 7 common types, and 7 unique or single types (strains No. 10, 12, $15,31,32,35,3)$ were observed. $\mathrm{F}$ type is the largest common type consisting of nine isolates and $\mathrm{B}, \mathrm{D}$, and $\mathrm{E}$ types contain two isolates separately. No band was observed in isolates No. 1, 2, 23, 29, and 40, and these four isolates were classified into $C$ type, which requires more accurate molecular typing techniques specifically sequencing-based methods to better identification of the isolates. Molecular typing of the analysis showed that the most frequent isolates belong to group $\mathrm{G}$.

\section{Discussion}

A. baumannii is an important nosocomial pathogen that is highly resistant to many antibiotics especially carbapenems, has been reported in recent years [20, 21]. In our study, more than $95 \%$ of isolated strains were resistant to antimicrobial agents except Colistin that all isolates were sensitive.

In Amin et al., study, 77 out of 85 MDR isolates were detected that only 2 isolates were resistant to Colistin which is inconsistent with a present study that all isolates were sensitive to Colistin. Also, blaVIM gene was the most common gene encoding $\mathrm{MBL}$ followed by blaIMP, blaSPM which is similar to our study [22]. In Ranjbar et al., a study in 2019, more than $93 \%$ of $A$. baumannii samples were resistant to the studied antibiotics, but high sensitivity to Polymyxin (100\%) and Colistin $(85.9 \%)$ was observed, indicating the effect of this antibiotic on Acinetobacter [23]. In the study by Fallah et al., 82 samples of $A$. baumannii were isolated from the burn hospital and divided into 14 types of ERICPCR patterns, including 11 common types and 3 unique types. In this study, 77 samples were classified into 9 main genotypes [24]. On the other hand, in the current

Table 2 High frequency genes and Strong biofilm formation in different clusters

\begin{tabular}{lllllllll}
\hline Cluster & A & B & C & D & E & F & G & H \\
\hline Frequency & 6 & 2 & 5 & 2 & 2 & 2 & 9 & 4 \\
& $(15 \%)$ & $(5 \%)$ & $(12 / 5 \%)$ & $(5 \%)$ & $(5 \%)$ & $(5 \%)$ & $(22 / 5 \%)$ & $(10 \%)$ \\
High frequency gene & VIM (14.7) & VIM (5.88) & SPM (15.78) & IMP (6.66) & IMP (13.33) & VIM (2.94) & SPM (36.84) & IMP (20) \\
Strong biofilm formation & $2(15.38)$ & $1(7.69)$ & 4 & $1(7.69)$ & 1 & $1(7.69)$ & 2 & 1 \\
& & & $(30.7)$ & & $(7.69)$ & & $(15.38)$ & $(7.69)$ \\
\hline
\end{tabular}




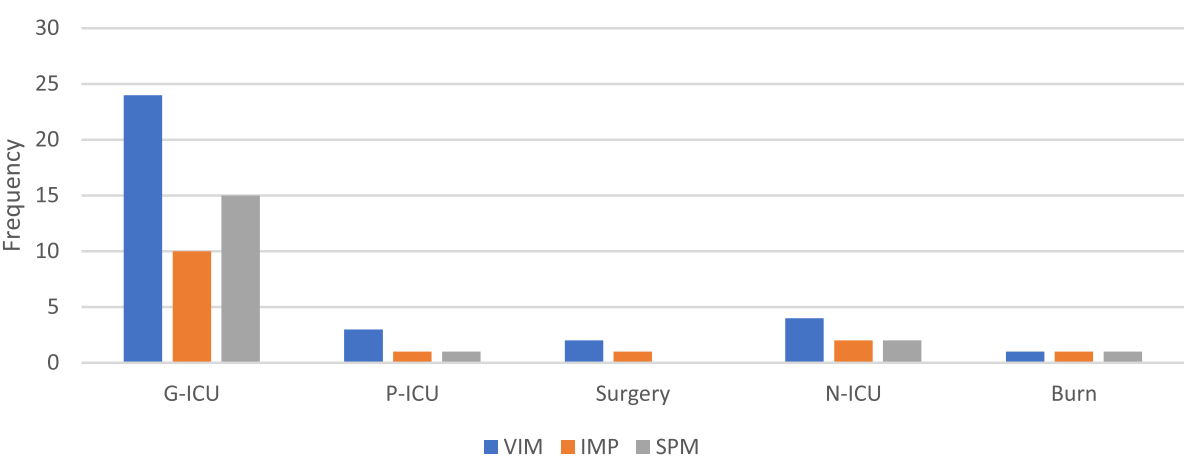

Fig. 2 Frequnces of MBL-producing genes in different wards

study 14 different ERIC-types including 7 common types and 7 unique or single types (Strains No. 10, 12, 15, 31, $32,35,3)$ were observed.

In the study of Zarifi et al., 80 samples of A. baumannii were isolated from ICU, which the highest frequency associated with trachea $92 \%$ similar to the present study (65\%). They showed that A. baumannii isolates were classified into 14 classes using ERIC-PCR [25]. Alamri et al., examined 207 samples of MDR A. baumannii, which the most common frequency similar to our study, was isolated from ICU (52.5\%), and ERIC-PCR was performed on meropenem-resistant isolates. Out of 131 samples was examined and divided into 4 groups of similar ERIC-PCR patterns according to their genotypes [26].

It is known that $A$. baumannii bacteria can form biofilms on surfaces and equipment in hospitals such as catheters tubes especially in ICUs [27]. A. baumannii strains with strong biofilm formation ability have less sensitivity to environmental conditions like dehydration than poor biofilm formation ones; So, biofilm production is crucial for bacterial survival under dry conditions [28-30].

In this study, we investigated antibiotic susceptibility, biofilm production, and clonal relationships of different clinical MDR A. baumannii isolates. The highest frequency of strong biofilm formation was seen in clusters

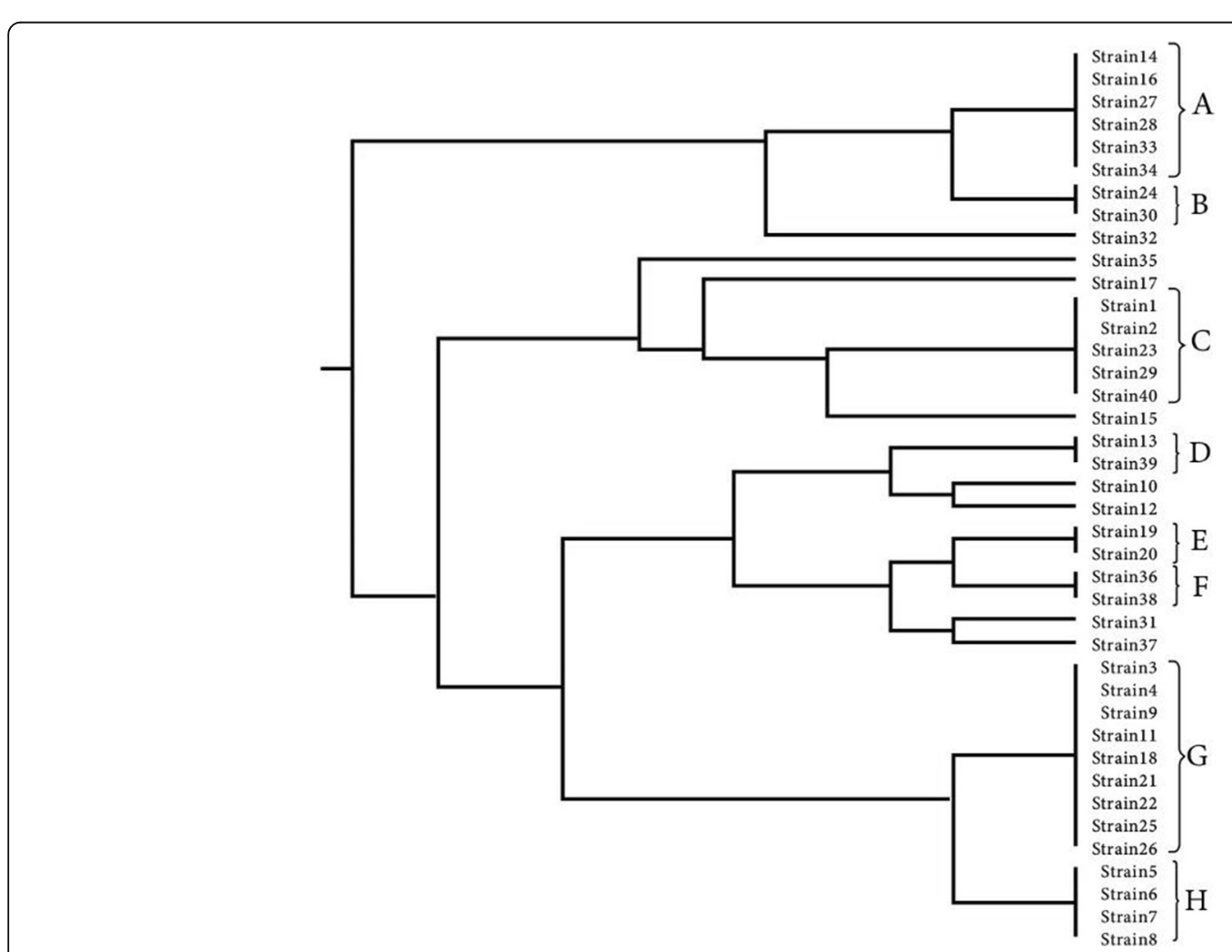

Fig. 3 Dendrogram of A. baumannii isolates clustering based on ERIC patterns 
Table 3 Frequency of clusters in different wards of the hospital

\begin{tabular}{lllllll}
\hline Clusture & G-ICU & P-ICU & Surgery & N-ICU & Burn & Total \\
\hline A & 5 & 0 & 0 & 1 & 0 & 6 \\
B & 0 & 0 & 1 & 0 & 1 & 2 \\
C & 2 & 2 & 0 & 0 & 1 & 5 \\
D & 0 & 0 & 0 & 1 & 1 & 2 \\
E & 1 & 0 & 0 & 0 & 1 & 2 \\
F & 1 & 0 & 1 & 0 & 0 & 2 \\
G & 8 & 0 & 0 & 1 & 0 & 9 \\
H & 2 & 1 & 1 & 0 & 0 & 4 \\
Total & 19 & 3 & 3 & 3 & 4 & 32 \\
\hline
\end{tabular}

C (30.7\%) and A (15.38\%) which indicates the relationship between ICU and the formation of a strong biofilm in $A$. baumannii, and no significant relationship was observed between strong biofilm and clusters. Also, considering that $95 \%$ of the samples were MDR, no significant difference was observed between antibiotic resistance and clusters. However, the presence of VIM gene in $A$. baumannii strains is common, there is also a significant relationship between VIM gene and clusters $(p=0.006)$, which indicates the association of resistance of this bacterium with different classes of antibiotics. In our study, there was no significant relationship between carbapenemase-producing genes and biofilm formation, which could be due to the limited samples. The highest frequency in our study was related to cluster G, which is isolated from G-ICU.

Results of our study showed that antimicrobial resistance in A. baumannii isolates from the different site of infections in a central hospital in Hamadan, Iran is dependent on several parameters, including the pattern of antibiotic administration in an area, geographical differences, and the extent to which nosocomial infections are evaluated and controlled and also findings of the study showed that local antibiotic prescription policies should be regularly monitored. Therefore, to better infection control, it is important to design programs such as controlling infections in different wards of hospitals, especially the intensive care unit, and antimicrobial resistance patterns should be monitored periodically in different regions.

It is also better in each hospital, using molecular methods such as ERIC-PCR, these bacteria are identified and their antibiotic resistance characteristics are determined and appropriate antibiotics are prescribed accordingly. Describing the relationship between clusters and genetic diversity in bacteria requires more extensive molecular studies.

\section{Conclusions}

The choice of a genotyping technique depends on the skill level of the users and the facilities of the laboratory as well as the purpose of the study. In the present study, the ERIC-PCR technique was used to genetically classify A. baumannii strains as one of the most important and common microorganisms in nosocomial infections. Overall, the findings of the present study showed that the ERIC-PCR method is a simple, fast, and low-cost method for describing the genetic diversity of different strains of $A$. baumannii.

However, it is recommended that more studies be performed on samples taken from different hospitals across the country and that the ERIC-PCR method be compared with newer molecular methods such as PFGE.

\section{Abbreviations}

ERIC-PCR: Enterobacterial Repetitive Intergenic Consensus-Polymerase chain reaction; MDR: multidrug-resistant; MBL: Metallo- $\beta$-lactamase;

MLST: Multilocus sequence typing; PFGE: Pulse Field Gel Electrophoresis

\section{Acknowledgements}

We are so thankful of Besat Hospital, Hamadan, Iran for sample preparation.

\section{Authors' contributions}

Data conceptualization and methodology were performed by M.T, L.S. Insilico prediction was performed by M.H, O.Z, and P.K. Analysis was performed by M.M, L.S and M.H collectively wrote the manuscript. M.T did the review and editing. The author(s) read and approved the final manuscript.

\section{Funding}

Hamadan University of Medical Sciences, Hamadan, Iran, funded this study.

\section{Availability of data and materials}

The datasets used and analyzed during the current study are available from the corresponding author on reasonable request.

\section{Declarations}

\section{Ethics approval and consent to participate}

This study has been approved by the ethics committee of the Hamadan University of Medical Sciences, Iran, and informed consent to participate was obtained from all subjects (Ethical approval No. IR.UMSHA.REC.1397.802). All methods were performed following the relevant guidelines and regulations.

Consent for publication

Not applicable.

\section{Competing interests}

The authors declare that they have no competing interests.

\section{Author details}

${ }^{1}$ Student Research Committee, Hamadan University of Medical Sciences, Hamadan, Iran. ${ }^{2}$ Department of Microbiology, Faculty of Medicine, Hamadan University of Medical Sciences, Hamadan, Iran.

Received: 22 January 2021 Accepted: 27 May 2021

Published online: 08 June 2021

\section{References}

1. Joly-Guillou M-L. Clinical impact and pathogenicity of Acinetobacter. Clinical microbiology and infection. 2005;11(11):868-73. https://doi.org/10.1111/j.14 69-0691.2005.01227.x

2. Saffari F, Monsen T, Karmostaji A, Azimabad FB, Widerström M. Significant spread of extensively drug-resistant Acinetobacter baumannii genotypes of clonal complex 92 among intensive care unit patients in a university hospital in southern Iran. Journal of Medical Microbiology. 2017;66(11): 1656-62. https://doi.org/10.1099/jmm.0.000619

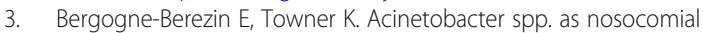
pathogens: microbiological, clinical, and epidemiological features. Clinical 
microbiology reviews. 1996;9(2):148. https://doi.org/10.1128/cmr.9.2.148-1 65.1996

4. Taitt CR, Leski TA, Stockelman MG, Craft DW, Zurawski DV, Kirkup BC, et al. Antimicrobial resistance determinants in Acinetobacter baumannii isolates taken from military treatment facilities. Antimicrobial agents and chemotherapy. 2014;58(2):767-81. https://doi.org/10.1128/aac.01897-13

5. Farshadzadeh Z, Hashemi FB, Rahimi S, Pourakbari B, Esmaeili D, Haghighi MA, et al. Wide distribution of carbapenem resistant Acinetobacter baumannii in burns patients in Iran. Frontiers in microbiology. 2015;6:1146. https://doi.org/10.3389/fmicb.2015.01146

6. Hujer KM, Hujer AM, Hulten EA, Bajaksouzian S, Adams JM, Donskey CJ, et al. Analysis of antibiotic resistance genes in multidrug-resistant Acinetobacter sp. isolates from military and civilian patients treated at the Walter Reed Army Medical Center. Antimicrobial agents and chemotherapy, 2006:50(12):4114-23. https://doi.org/10.1128/aac.00778-06

7. Brown NG, Horton LB, Huang W, Vongpunsawad S, Palzkill T. Analysis of the functional contributions of Asn233 in metallo- $\beta$-lactamase IMP-1. Antimicrobial agents and chemotherapy. 2011;55(12):5696-702. https://doi. org/10.1128/aac.00340-11

8. Noori M, Karimi A, Fallah F, Hashemi A, Alimehr S, Goudarzi H, et al. High Prevalence of Metallo-beta-lactamase Producing Acinetobacter. Arch Pediatr. 2014;2(3):e15439. https://doi.org/10.5812/pedinfect.15439

9. Eze EC, Chenia HY, El Zowalaty ME. Acinetobacter baumannii biofilms: effects of physicochemical factors, virulence, antibiotic resistance determinants, gene regulation, and future antimicrobial treatments. Infection and Drug Resistance. 2018;11:2277. https://doi.org/10.2147/idr. s169894

10. Meshkat Z, Salimizand $H$, Amini $Y$, Khakshoor M, Mansouri D, Farsiani H, et al. Molecular characterization and genetic relatedness of clinically Acinetobacter baumanii isolates conferring increased resistance to the first and second generations of tetracyclines in Iran. Annals of Clinical Microbiology and Antimicrobials. 2017;16(1):51. https://doi.org/10.1186/s12 941-017-0226-9

11. jun Li Y, zhi Pan $C$, quan Fang $C$, xiang Zhao $Z$, ling Chen $H$, hao Guo $P$, et al. Pneumonia caused by extensive drug-resistant Acinetobacter baumannii among hospitalized patients: genetic relationships, risk factors and mortality. BMC infectious diseases. 2017;17(1):371. https://doi.org/10.11 86/s12879-017-2471-0

12. Gherardi G, Creti R, Pompilio A, Di Bonaventura G. An overview of various typing methods for clinical epidemiology of the emerging pathogen Stenotrophomonas maltophilia. Diagnostic microbiology and infectious disease. 2015;81(3):219-26. https://doi.org/10.1016/j.dia gmicrobio.2014.11.005

13. Silbert S, Pfaller MA, Hollis RJ, Barth AL, Sader HS. Evaluation of three molecular typing techniques for nonfermentative Gram-negative bacilli. Infection control and hospital epidemiology. 2004;25(10):847-51. https://doi. org/10.1086/502307

14. Aljindan R, Alsamman K, Elhadi N. ERIC-PCR genotyping of Acinetobacter baumannii isolated from different clinical specimens. Saudi journal of medicine \& medical sciences. 2018;6(1):13. https://doi.org/10.4103/sjmms. sjmms_138_16

15. Londero A, Costa M, Sucari A, Leotta G. Comparison of three molecular subtyping techniques for Listeria monocytogenes. Revista Argentina de Microbiología. 2019;51(4):359-62. https://doi.org/10.1016/j.ram.2019.01.003

16. Moosavian M, Emam N. The first report of emerging mobilized colistinresistance (mcr) genes and ERIC-PCR typing in Escherichia coli and Klebsiella pneumoniae clinical isolates in southwest Iran. Infection and drug resistance. 2019;12:1001. https://doi.org/10.2147/idr.s192597

17. Codjoe FS, Brown CA, Smith TJ, Miller K, Donkor ES. Genetic relatedness in carbapenem-resistant isolates from clinical specimens in Ghana using ERICPCR technique. PLoS One. 2019;14(9):e0222168. https://doi.org/10.1371/ journal.pone.0222168

18. Clinical, Institute LS. Performance standards for antimicrobial susceptibility testing. Clinical and Laboratory Standards Institute Wayne, PA; 2017.

19. Wang M, Wei H, Zhao Y, Shang L, Di L, Lyu C, et al. Analysis of multidrugresistant bacteria in 3223 patients with hospital-acquired infections (HAl) from a tertiary general hospital in China. Bosnian Journal of Basic Medical Sciences. 2019;19(1):86. https://doi.org/10.17305/bjbms.2018.3826

20. Bahador A, Taheri M, Pourakbari B, Hashemizadeh Z, Rostami H, Mansoori N, et al. Emergence of rifampicin, tigecycline, and colistin-resistant Acinetobacter baumannii in Iran; spreading of MDR strains of novel
International Clone variants. Microbial Drug Resistance. 2013;19(5):397-406. https://doi.org/10.1089/mdr.2012.0233

21. Bahador A, Bazargani A, Taheri M, Hashemizadeh Z, Khaledi A, Rostami H, et al. Clonal lineages and virulence factors among Acinetobacter baumannii isolated from Southwest of Iran. J Pure Appl Micribiol. 2013;7:1559-66.

22. Amin M, Navidifar T, Shooshtari FS, Goodarzi $H$. Association of the genes encoding metallo- $\beta$-lactamase with the presence of integrons among multidrug-resistant clinical isolates of Acinetobacter baumannii. Infection and drug resistance. 2019;12:1171. https://doi.org/10.2147/idr.s196575

23. Ranjbar R, Farahani A. Study of genetic diversity, biofilm formation, and detection of Carbapenemase, MBL, ESBL, and tetracycline resistance genes in multidrug-resistant Acinetobacter baumannii isolated from burn wound infections in Iran. Antimicrobial Resistance \& Infection Control. 2019;8(1):172. https://doi.org/10.1186/s13756-019-0612-5

24. Falah F, Shokoohizadeh L, Adabi M. Molecular identification and genotyping of Acinetobacter baumannii isolated from burn patients by PCR and ERICPCR. Scars, burns \& healing. 2019;5:2059513119831369. https://doi.org/10.11 77/2059513119831369

25. Zarifi E, Ghazalibina M, Mansouri S, Morshedi K, Pourmajed R, Arfaatabar M. Molecular typing of Acinetobacter baumannii clinical strains by enterobacterial repetitive intergenic consensus polymerase chain reaction (ERIC-PCR). Gene Reports. 2020;18:100542. https://doi.org/10.1016/j.genrep.2 019.100542

26. Alamri AM, Alsultan AA, Ansari MA, Alnimr AM. Biofilm-Formation in Clonally Unrelated Multidrug-Resistant Acinetobacter baumannii Isolates. Pathogens. 2020;9(8):630. https://doi.org/10.3390/pathogens9080630

27. Rodríguez-Baño J, Marti S, Soto S, Fernández-Cuenca F, Cisneros JM, Pachón $J$, et al. Biofilm formation in Acinetobacter baumannii: associated features and clinical implications. Clinical microbiology and infection. 2008;14(3):2768. https://doi.org/10.1111/j.1469-0691.2007.01916.x

28. Davey ME, O'toole GA. Microbial biofilms: from ecology to molecular genetics. Microbiology and molecular biology reviews. 2000;64(4):847-67.

29. Bhargava N, Sharma P, Capalash N. Quorum sensing in Acinetobacter: an emerging pathogen. Critical reviews in microbiology. 2010;36(4):349-60. https://doi.org/10.3109/1040841x.2010.512269

30. Movahedi M, Zarei O, Hazhirkamal M, Karami P, Shokoohizadeh L, Taheri M. Molecular typing of Escherichia coli strains isolated from urinary tract infection by ERIC-PCR. Gene Reports. 2021;23:101058. https://doi.org/10.101 6/j.genrep.2021.101058.

\section{Publisher's Note}

Springer Nature remains neutral with regard to jurisdictional claims in published maps and institutional affiliations.
Ready to submit your research? Choose BMC and benefit from:
- fast, convenient online submission
- thorough peer review by experienced researchers in your field
- rapid publication on acceptance
- support for research data, including large and complex data types
- gold Open Access which fosters wider collaboration and increased citations
- maximum visibility for your research: over $100 \mathrm{M}$ website views per year
At BMC, research is always in progress.
Learn more biomedcentral.com/submissions 